\title{
COGNITIVE LINGUISTICS
}

EDITOR-IN-CHIEF

John Newman

University of Alberta, Canada

ASSOCIATE EDITORS

Mirjam Fried

Charles University, Prague,

Czech Republic

Stefan Th. Gries

University of California at

Santa Barbara, USA

Laura A. Janda

University of Tromsø, Norway

Zoltán Kövecses

Eötvös Loránd University, Budapest,

Hungary

Teenie Matlock

University of California, Merced, USA

John R. Taylor

University of Otago, Dunedin,

New Zealand

\section{REVIEW EDITOR}

Martin Pütz

Universität Koblenz-Landau, Germany

EDITORIAL ASSISTANT

Claudia Heinrich

E-mail: cogling@ualberta.ca

\section{DE GRUYTER}

MOUTON 


\section{Editorial Board}

Antonio Barcelona

University of Cordoba, Spain

Joan L. Bybee

University of New Mexico at

Albuquerque, USA

Paul Chilton

Lancaster University, UK

William Croft

University of New Mexico at

Albuquerque, USA

Ewa Dabrowska

Northumbria University, UK

Holger Diessel

University of Jena, Germany

Dagmar Divjak

University of Sheffield, UK

Ad Foolen

Radboud University, The Netherlands

Dirk Geeraerts

University of Leuven, Belgium

Raymond W. Gibbs

University of California at Santa Cruz, USA

Adele E. Goldberg

Princeton University, USA

Tuomas Huumo

University of Turku, Finland

Iraide Ibarretxe

University of Zaragoza, Spain

Seizi Iwata

Kansai University, Japan
Ronald W. Langacker

University of California at San Diego, USA

Francisco J. Ruiz de Mendoza Ibáñez Universidad de La Rioja, Spain

Brigitte Nerlich

University of Nottingham, UK

Klaus-Uwe Panther

University of Hamburg, Germany

Martin Pütz

University of Koblenz-Landau,

Germany

Günter Radden

University of Hamburg, Germany

Sally Rice

University of Alberta, Canada

Hans Joerg Schmid

Ludwig-Maximilians-University,

Munich, Germany

Dan I. Slobin

University of California, Berkeley, USA

Elizabeth Closs Traugott

Stanford University, USA

Javier Valenzuela

University of Murcia, Spain

Arie Verhagen

Leiden University, The Netherlands

Marjolijn Verspoor

Groningen University, The Netherlands

Jörg Zinken

University of Portsmouth, UK 


\section{Contents}

Karen Sullivan and Elena Bandín

Censoring metaphors in translation: Shakespeare's Hamlet under

Franco 177

Lorena Pérez Hernández

Cognitive grounding for cross-cultural commercial communication -203

\section{Egbert Fortuin}

Deconstructing a verbal illusion: The 'No $X$ is too $Y$ to $Z$ ' construction and the rhetoric of negation -249

Ben Ambridge, Claire H. Noble and Elena V. M. Lieven

The semantics of the transitive causative construction: Evidence from a forcedchoice pointing study with adults and children -293

\section{Commentary}

Mario Brdar and Rita Brdar-Szabó

Where does metonymy begin? Some comments on Janda (2011) _ 313

\section{Reply}

Laura A. Janda

Metonymy and word-formation revisited - 341 